\title{
Mobility of Trace Elements in Pore Solutions of Portland Cement Pastes Exposed to Leaching
}

\author{
Marija Đuroković, ${ }^{1, *}$ Dubravka Matković-Čalogović, ${ }^{2}$ Ivan Janotka ${ }^{3}$
}

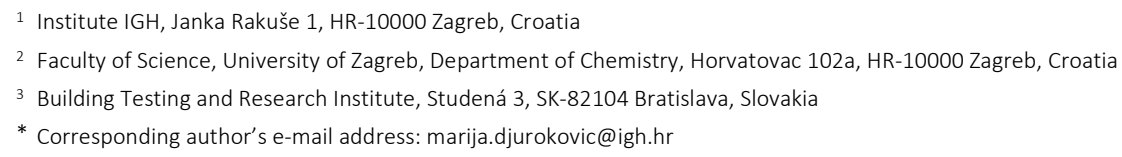

RECEIVED: April 8, 2019 औ REVISED: June 14, 2019 \ ACCEPTED: June 17, 2019

\begin{abstract}
Two Portland cement pastes, CEM I 42.5R and CEM III/A 52.5N were exposed to leaching by soft water throughout a one-year hydration period. Mobility of trace elements was investigated by determination of their pore solution concentration in the course of time. Eleven trace elements were included in this research: antimony, arsenic, cadmium, chromium, cobalt, copper, mercury, nickel, lead, vanadium and zinc. The possible usage of the pore solution trace elements concentration in monitoring of deleterious leaching reactions and prediction of environmental risk was investigated.
\end{abstract}

Keywords: Portland cement paste, trace elements, leaching.

\section{INTRODUCTION}

NTEREST in trace elements incorporated in Portland cement has increased over the last several decades due to the increased waste utilization as a partial substitution of primary raw materials and fuels in its production. Some of these elements are toxic or carcinogenic (arsenic, cadmium, cobalt, chromium, copper, mercury, nickel, lead) or present an important occupational risk (chromium, cobalt, nickel).[1] Transition metals (cobalt, chromium, copper, manganese, nickel, vanadium, titanium, zinc) also have influence on the process reaction during clinkerization and on the properties of the final product. ${ }^{[2]}$

The mechanism and place of immobilization depends on the quantity of the trace element present in Portland cement. ${ }^{[3]}$ At a low concentration, potentially hazardous trace elements are immobilized in the principal clinker phases: tricalcium silicate (further: alite), dicalcium silicate (further: belite), tricalcium aluminate (further: aluminate); tetracalcium aluminoferrite (further: ferrite), free lime or periclase. When the concentration of the element increases above the threshold limit, new phases are formed. ${ }^{[3]}$ The binding mechanism of the specific trace element depends on its chemical properties. ${ }^{[4]}$ These properties largely depend on the oxidative state of the element which is a function of the raw materials chemistry and production conditions. ${ }^{[5]}$

A lot of research on incorporation of the trace elements in Portland cement has been carried out. ${ }^{[6-18]}$ Oxidative states of chromium in Portland clinker are $+3,+4,+5$ and $+6 .{ }^{[6]}$ At high temperatures and in an oxidizing atmosphere during production the oxidative state +3 is the most stable one. Chromium in this oxidative state is concentrated in ferrite due to its replacement with $\mathrm{Fe}^{3+}$. Chromium ions in higher oxidative states $(+4,+5)$ are smaller and replacement of $\mathrm{Al}$ and $\mathrm{Si}$ in the silicate phases is possible. ${ }^{[5]}$ Sinyoung et al. have confirmed existence of individual phases of chromium in different oxidative states.[6] The oxidative states +2 and +3 have been confirmed for cobalt in clinker, being concentrated in the ferrite phase. ${ }^{[2,5,7]}$ Copper and nickel are mainly incorporated in ferrite, followed by alite, aluminate and belite. ${ }^{[8]}$ Formation of a copper solid solution in free lime has been confirmed for higher uptakes. ${ }^{[9,10]}$ Nickel can form an individual compound $\left(\mathrm{MgNiO}_{2}\right)$ with magnesium. ${ }^{[11]}$ Vanadium in clinker is present in the form of $\mathrm{V}_{2} \mathrm{O}_{5}$ and has preferential partition

(c) Br 
towards belite. ${ }^{[2,8]}$ Bolio-Arceo et al. have confirmed that most of the zinc is present in form of a solid solution based on $6 \mathrm{CaO} \cdot 3 \mathrm{ZnO} \cdot 2 \mathrm{Al}_{2} \mathrm{O}_{3} \cdot{ }^{[12]} \mathrm{A}$ small amount of the zinc is partitioned into the solid solution of the main clinker phases. ${ }^{[8,13]}$ Cadmium is incorporated in alite, belite and free lime. Belite has higher ability to incorporate cadmium than alite. ${ }^{[14]}$ Metalloids, arsenic and antimony are present as individual phases, both in the oxidative state +5 . ${ }^{[15-17]}$ Incorporation of mercury and lead within the clinker phases has not been researched well. These elements are difficult to stabilize within the Portland clinker due to their volatility. They are concentrated in the filter dust or off gases. ${ }^{[18]}$

Following the primary hydration, trace elements are transferred to the hydration products in the Portland cement paste. The most abundant hydration phases are: amorphous calcium silicate hydrate (further: C-S-H gel), calcium hydroxide (further: portlandite or $\mathrm{CH}$ ); aluminate ferrate trisulfate (further: $\mathrm{AFt}$ ) and aluminate ferrate monosulphate (further: AFm) and hydrogarnet. ${ }^{[19]}$ Coke et al. have showed that trace elements can be immobilized by multiple mechanisms: chemisorption, precipitation, formation of surface compounds on any cement component surface, inclusion and chemical incorporation. ${ }^{[20]}$ Cadmium, cobalt, nickel, lead and zinc are present in the Portland cement paste in the oxidative state $+2 .{ }^{[18]}$ For nickel and cobalt the oxidative state +3 has been also confirmed. [21] Immobilization of $\mathrm{Cd}^{2+}, \mathrm{Co}^{2+}, \mathrm{Pb}^{2+}$ and $\mathrm{Zn}^{2+}$ within the AFt phase at the $\mathrm{M}^{2+}$ site has been reported. ${ }^{[21,22]}$ Cadmium, lead and zinc also precipitate in the form of hydroxide, carbonate and nitrate mixed salts. ${ }^{[21,23]}$ Substitution of $\mathrm{Ca}^{2+}$ by $\mathrm{Pb}^{2+}$ ions in all hydrated phases has been suggested by different authors. ${ }^{[22,24]}$ Cadmium hydroxide provides the nucleation sites for precipitation of calcium hydroxide and the C-S-H gel. ${ }^{[23,25]}$ Chemical mobilization of cadmium in the C-S-H gel has been confirmed. ${ }^{[26]}$ Sorption of cobalt on C-S$\mathrm{H}$ in pure hydrated phases has been found. ${ }^{[27]}$ Substitution of $\mathrm{Al}^{3+}$ with $\mathrm{Co}^{3+}$ ions in AFt was also reported. ${ }^{[21]}$ Atkins et al. have showed that nickel is present in the form of a nickel hydroxide gel intermixed with C-S-H. ${ }^{[28]}$ Formation of Ni-Al layered double hydroxides has been confirmed in the Portland cement paste. ${ }^{[29,30]}$ Sorption of nickel on the $\mathrm{C}-\mathrm{S}-\mathrm{H}$ gel has been also reported. ${ }^{[31]}$ Zinc is immobilized in AFt and C-S-H phases. ${ }^{[18]}$ It has a strong affinity for the hydrated ferrite phase. ${ }^{[32]}$ For higher zinc concentrations precipitation of $\beta_{2}-\mathrm{Zn}(\mathrm{OH})_{2}$ and calcium zincate, $\mathrm{Zn} 2 \mathrm{Ca}(\mathrm{OH})_{6} \cdot 2 \mathrm{H}_{2} \mathrm{O}$, has been reported. ${ }^{[33,34]}$ Ion exchange of calcium with copper in the $\mathrm{C}-\mathrm{S}-\mathrm{H}$ gel has been indicated. ${ }^{[27]}$ Substitution of the sulphate ion in $\mathrm{AFt}$ with vanadate $\left(\mathrm{VO}_{4}{ }^{-}\right)$, chromate $\left(\mathrm{CrO}_{4}{ }^{2-}\right)$ and arsenate $\left(\mathrm{AsO}_{4}{ }^{3-}\right)$ has been experimentally confirmed. ${ }^{[34,35]}$ Incorporation in small quantities in the hydrogarnet, the substitution of $\mathrm{Al}$ in $\mathrm{AFt}$ and of $\mathrm{Si}$ in $\mathrm{C}-\mathrm{S}-\mathrm{H}$ have been reported for chromium in the oxidative state +3 . ${ }^{[26,32]}$ Phenrat et al. have confirmed arsenic sorption on the C-S-H surface and formation of solubility-limiting Ca-As compounds. ${ }^{[36]}$ Some authors have confirmed precipitation of magnesium and calcium arsenate in the amorphous rather than in the crystalline form. ${ }^{[16,37]}$ In the high alkaline media antimony exists as an antimonate oxo-anion $\left(\mathrm{Sb}(\mathrm{OH})_{6}^{-}\right)$. The precipitation of calcium antimonate in the Portland cement paste is not supported due to its $\mathrm{pH}$ independent solubility. ${ }^{[38]}$ Cornelis et al. have shown that antimonate forms a solid solution predominantly with AFm and the $\mathrm{C}-\mathrm{S}-\mathrm{H}$ gel. For the higher concentrations of antimony (1000 $\mathrm{g} \mathrm{kg}^{-1}$ ), the formation of romeite with a general formula $\mathrm{Ca}_{1}+x \mathrm{Sb}_{2} \mathrm{O}_{6} \mathrm{OH}_{2-2 x}$ has been proposed. ${ }^{[39]}$ The composition and the structure of romeite changes with $\mathrm{pH}$ and the concentration of available calcium ions. ${ }^{[40]}$ Immobilization of mercury in AFt by physical encapsulation has been confirmed. ${ }^{[21]}$

Small fractions of trace elements are dissolved in pore solutions within the capillary pores of hydrated Portland cement pastes. The pore solution has been considered as an alkali hydroxide solution with hydroxide ions, sodium, potassium, calcium, sulfate, silicon and aluminium as the principle dissolved ions. Relations between the concentration of principal ions in the pore solution and its variations at different times of hydration have been dealt with by a large number of investigators. ${ }^{[41-51]}$ A very detailed literature review of pore solution research has been given by Vollpracht. ${ }^{[52]}$ Research on the trace elements in the pore solution is less often encountered in the literature. Kempel et al. have reported the total content of the selected trace elements (lithium, barium, strontium, iron, aluminium and silicon) in hydrated and carbonated Portland cement pastes. ${ }^{[53]}$ The research of Díez et al. on immobilization of cadmium in the Portland cement paste has shown a low concentration of cadmium in the pore solution. ${ }^{[4]}$ Vollpracht et al. have investigated development of the concentrations of selected elements (antimony, barium, chromium, lead, molybdenum and vanadium) in pore solutions of Portland cement pastes exposed to leaching throughout a 28 days period. ${ }^{[54]}$ During the service life the Portland cement paste is exposed to weathering and degradation. Soft water containing a low concentration of dissolved ions in contact with the Portland cement paste induces decalcification. ${ }^{\left[{ }^{55,56]}\right.}$ A decrease of calcium ions in the pore solution induces hydrolysis and leaching of the calcium containing hydration products. ${ }^{[57,58]}$ The susceptibility towards soft water decreases in the order portlandite, AFm, AFt. C-S-H gel. ${ }^{[59]}$ Decalcification of the C-S-H gel gradually decreases the $\mathrm{Ca} / \mathrm{Si}$ ratio. ${ }^{[60]}$ In the leached Portland cement paste, the secondary precipitation of AFm, AFt and calcite, appears. ${ }^{[61,62]}$ Dissolution of portlandite induces macro-porosity of the cement paste and the loss of calcium from the C-S-H gel induces micro-porosity. ${ }^{[63,58]}$ The increased porosity and permeability and loss of mechanical 
strength are the key consequences in the structures exposed to leaching. ${ }^{[60,64-66]}$ These processes may affect immobilization of the trace elements and their concentrations in the pore solution, especially on the long term scale. Hooton et al. have shown that understanding of the pore solution chemistry can be used to understand deleterious reactions such as the alkali-silicate reaction, reinforcement corrosion resistance or delayed ettringite formation. ${ }^{[63]}$ The increased mobility of the trace elements may increase the possible environmental risk.

Leaching appears in Portland cement pastes exposed to steam, fog, rainwater or groundwater. ${ }^{[67]}$ This is a significant issue for structures constantly exposed to soft or acid waters such as dams, water tanks, pipes or nuclear waste storages. ${ }^{[60]}$ It is also very important for the waste solidification and stabilization by Portland cement. ${ }^{[68]}$

This paper summarizes results of the research on the mobility of eleven trace elements in Portland cement pore solutions exposed to leaching throughout a 365 day hydration period. The possible usage of the concentration of pore solution trace elements in monitoring of deleterious leaching reactions and prediction of the environmental risk was investigated. The tank leaching test was implemented and pure soft water was used as the leaching agent. The impact on the mechanical properties was monitored by measuring flexural and compressive strength. Two Portland cement types (CEM I 42.5R and CEM III/A 52.5N) and eleven trace elements were included in this research: antimony, arsenic, cadmium, chromium, cobalt, copper, mercury, nickel, lead, vanadium and zinc. The research is a part of boarder project dealing with levels of trace elements in construction products initiated by Institute IGH.

\section{EXPERIMENTAL}

\section{Materials and Methods}

Two types of Portland cement, CEM I 42.5R (further: CEM I) and blast furnace cement CEM III/A 52.5N (further: CEM III) according to the standard designation, were selected for this research. ${ }^{[69]}$ Both cement types have Croatian origin. These two cement types were selected since they have different composition. Thus, different levels of trace elements were expected. Substitution of 35-64\% of clinker with granulated blast furnace slag in CEM III is allowed by standard HRN EN 197-1. ${ }^{[69]}$ The maximum allowed clinker replacement for CEM I given by the same standard is $5 \%$. Cement composition was determined by the standard wet chemistry methods and are reported in Table 1. ${ }^{[70]}$ The diffraction patterns for CEM I and CEM III were recorded by the powder X-ray diffraction method (further: PXRD) on an Panalytical X'pert MPD PRO diffractometer in Bragg-
Brentano geometry with $\mathrm{CuK} \alpha_{1}$ radiation $(\lambda=1.5406 \AA$ ) and shown in Figure 1. The Rietveld method was used for quantitative phase analysis using the Panalytical HighScore Software Suite. ${ }^{[71]}$ The major clinker phases: alite, belite, aluminate and ferrite together with the glass phase were determined (see Table 2). The standard wet chemistry methods were used to determine major oxides. ${ }^{[72]}$ The chemical compositions of used CEM I and CEM III are reported in Table 3 together with the abbreviations for the major oxides usually used to simplify the formulas.

Soft water was used to prepare and cure cement pastes and to encourage leaching. Levels of calcium and magnesium and the selected trace elements ( $\mathrm{As}, \mathrm{Cd}, \mathrm{Co}, \mathrm{Cr}$, $\mathrm{Cu}, \mathrm{Hg}, \mathrm{Ni}, \mathrm{Pb}, \mathrm{Sb}, \mathrm{V}$ and $\mathrm{Zn}$ ) in soft water were measured by inductively coupled plasma mass spectrometry, ICP-MS (Agilent 7800, Agilent, Santa Clara, CA, USA). The hardness

Table 1. Composition of CEM I and CEM III.

\begin{tabular}{ccc}
\hline Cement & $w$ (clinker) $/ \%$ & $w$ (Granulated blasfurnace slag) $/ \%$ \\
\hline CEM I & 100 & - \\
CEM III & 36.0 & 64.0 \\
\hline
\end{tabular}

Table 2. Phase composition of CEM I and CEM III.

\begin{tabular}{ccc}
\hline Mineral & $w($ CEM I) $/ \%$ & $w($ CEM II) $/ \%$ \\
\hline$C_{3}$ S (alite) & 70 & 41 \\
$C_{2}$ S (belite) & 12.7 & 3.7 \\
$C_{3} \mathrm{~A}$ (aluminate) & 2.9 & 3.2 \\
$\mathrm{C}_{4} \mathrm{AF}$ (ferrite) & 3.5 & 8.1 \\
calcite & 4.7 & 2.2 \\
glass phase & 0 & 38 \\
\hline
\end{tabular}

Table 3. Mass fractions of major elements (expressed as oxides) in CEM I and CEM III.

\begin{tabular}{cccc}
\hline \multicolumn{2}{c}{ Oxide } & \multicolumn{2}{c}{$w / \%$} \\
\hline Name & Designation & $\mathrm{CEM} \mathrm{I}$ & $\mathrm{CEM} \mathrm{II}$ \\
\hline Loss on ignition, $\left(950 \pm 50^{\circ} \mathrm{C}\right)$ & - & 2.89 & 1.40 \\
$\mathrm{CaO}$ & $\mathrm{C}$ & 62.90 & 56.25 \\
$\mathrm{MgO}$ & $\mathrm{M}$ & 2.30 & 3.19 \\
$\mathrm{SiO}_{2}$ & $\mathrm{~S}$ & 19.53 & 26.29 \\
$\mathrm{Al}_{2} \mathrm{O}_{3}$ & $\mathrm{~A}$ & 4.58 & 6.20 \\
$\mathrm{Fe}_{2} \mathrm{O}_{3}$ & $\mathrm{~F}$ & 2.82 & 1.93 \\
$\mathrm{SO}_{3}$ & $\overline{\mathrm{S}}$ & 3.07 & 2.40 \\
$\mathrm{~K}_{2} \mathrm{O}$ & $\mathrm{K}$ & 0.92 & 0.67 \\
$\mathrm{Na}_{2} \mathrm{O}$ & $\mathrm{N}$ & 0.17 & 0.15 \\
\hline
\end{tabular}


of water was $0.04 \mathrm{mg}$ equivalent $\mathrm{CaCO}_{3} / \mathrm{L}$, computed from the determined concentration of calcium and magnesium using the formula: Hardness $=2.497\left[\mathrm{Ca}, \mathrm{mg} \mathrm{L}^{-1}+4.118[\mathrm{Mg}\right.$, $\mathrm{mg} \mathrm{L}^{-1}$. The standard procedure for water analysis without previous digestion was applied. ${ }^{[73]}$ The total concentration of the selected eleven trace elements and hardness are reported in Table 4.

\section{Sample Preparation and Leaching}

Cement pastes were prepared with the water to cement ratio $(w / c)$ of 0.50 using the standard mortar mixer and the standard procedure with a modification in cement content: $1000 \mathrm{~g}$ of cement was used and the amount of water was adjusted to get $w / c$ of $0.50 . .^{[74]}$ Immediately after mixing, the prepared pastes were transferred to the standard moulds without undue compaction or vibration and the voids were removed by gentle tapping. Excess of the paste edged ruler. The filled moulds were stored in a moist air cabinet at a temperature of $20.0 \pm 1.0{ }^{\circ} \mathrm{C}$ and relative humidity not less than $90 \%$ for 24 hours. The tank leaching test was used in this research with prismatic samples of dimensions $40 \times 40 \times 160 \mathrm{~mm}$. The prepared samples were cured in plastic tanks filled with soft water at $20.0 \pm 2.0^{\circ} \mathrm{C}$ after demoulding (Figure 2). The volume of water was adjusted to provide the ratio of the surface of the samples and the volume of water of $1: 10$. The plastic tanks with the stored cement pastes were covered with a plastic cover to prevent evaporation. No additional protection against carbon dioxide from air was used. Curing water was changed three times a week (Monday, Wednesday and Friday) to provide an aggressive attack of the water media during the hydration period. Cement pastes were cured for 2, 7, 28, $56,90,180$ and 365 days.

\section{Strength Determination}

Flexural and compressive strength was determined on the prepared and cured prismatic samples according to the standard procedure. ${ }^{[74]}$ The standard flexural and compressive testing machine was used. Standard rates of $50 \pm 10 \mathrm{~N} \mathrm{~s}^{-1}$ for flexural and $2400 \pm 200 \mathrm{~N} \mathrm{~s}^{-1}$ for compressive strength were applied to break the prismatic samples. The flexural strength was calculated as the arithmetic mean of three, and the compressive of six individual results. The results are reported in Table 5.

\section{Obtaining Pore Solutions}

Pore solution was expelled from the samples using the equipment shown in Figure 3. It consisted of two steel bodies with two inner concentric cylinders where the tested samples were placed. The sample was followed by a piston, to which the pressure of $150 \mathrm{MPa}$ and the gain power in $0.5 \mathrm{kN} \mathrm{mm}^{-2} \mathrm{~s}^{-1}$ was applied. The porous steel lamina was was removed by a gentle sawing motion with a straight-

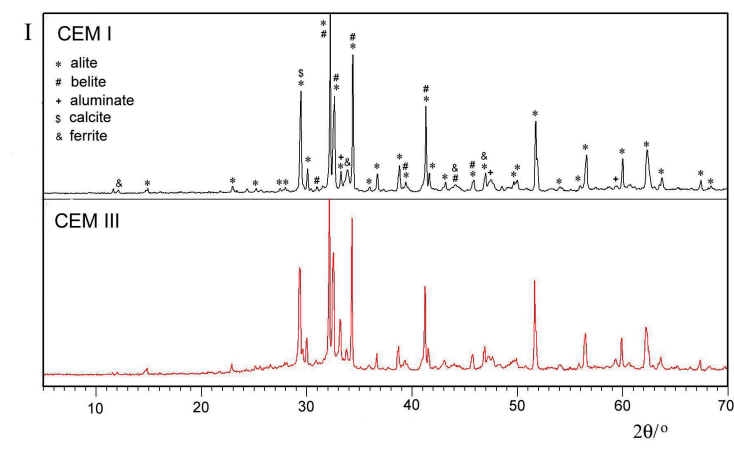

Figure 1. PXRD of CEM I and CEM III in the $2 \theta$ range $5-70^{\circ}$. The crystalline phases identified in CEM I are also present in CEM III. The high background indicates a significant amount of the amorphous phase in CEM III as a consequence of added granulated blast furnace slag.

Table 4. Concentration of trace elements in soft water.

\begin{tabular}{cc}
\hline Element & Concentration $/ \mu \mathrm{g} \mathrm{L}^{-1}$ \\
\hline $\mathrm{As}$ & $<0.030$ \\
$\mathrm{Cd}$ & $<0.006$ \\
$\mathrm{Co}$ & $<0.008$ \\
$\mathrm{Cr}$ & $<0.056$ \\
$\mathrm{Cu}$ & $<0.203$ \\
$\mathrm{Hg}$ & $<0.009$ \\
$\mathrm{Ni}$ & $<0.042$ \\
$\mathrm{~Pb}$ & $<0.080$ \\
$\mathrm{Sb}$ & $<0.005$ \\
$\mathrm{~V}$ & $<0.020$ \\
$\mathrm{Zn}$ & $<1.06$ \\
$\mathrm{Ca}$ & $0.013 \mathrm{mg} \mathrm{L}^{-1}$ \\
$\mathrm{Mg}$ & $0.003 \mathrm{mg} \mathrm{L}^{-1}$ \\
\hline
\end{tabular}

Table 5. Mass fractions of major elements (expressed as oxides) in CEM I and CEM III.

\begin{tabular}{|c|c|c|c|c|}
\hline \multirow{3}{*}{$\begin{array}{l}\text { Hydration } \\
\text { period / days }\end{array}$} & \multicolumn{4}{|c|}{ Strength / MPa } \\
\hline & \multicolumn{2}{|c|}{ Flexural } & \multicolumn{2}{|c|}{ Compressive } \\
\hline & CEM I & CEM II & CEM I & CEM II \\
\hline 2 & 3.5 & 3.9 & 19.3 & 20.0 \\
\hline 7 & 5.1 & 5.6 & 31.3 & 31.9 \\
\hline 28 & 7.2 & 7.8 & 49.4 & 51.8 \\
\hline 56 & 8.2 & 8.6 & 57.0 & 60.7 \\
\hline 90 & 8.7 & 9.1 & 61.3 & 65.7 \\
\hline 180 & 9.2 & 4.3 & 65.0 & 69.1 \\
\hline 365 & 4.9 & 4.2 & 56.0 & 42.3 \\
\hline
\end{tabular}

Croat. Chem. Acta 2019, 92(1), 103-114

DOI: $10.5562 /$ cca3511 


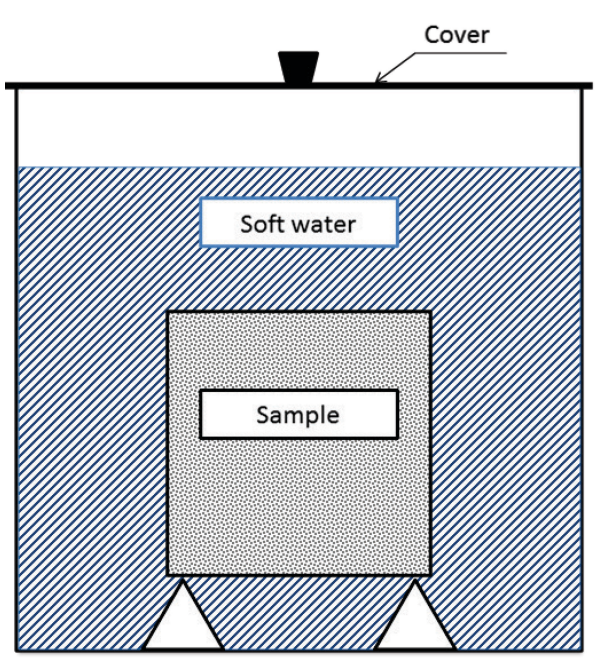

Figure 2. Schematic diagram of the tank for the leaching test.

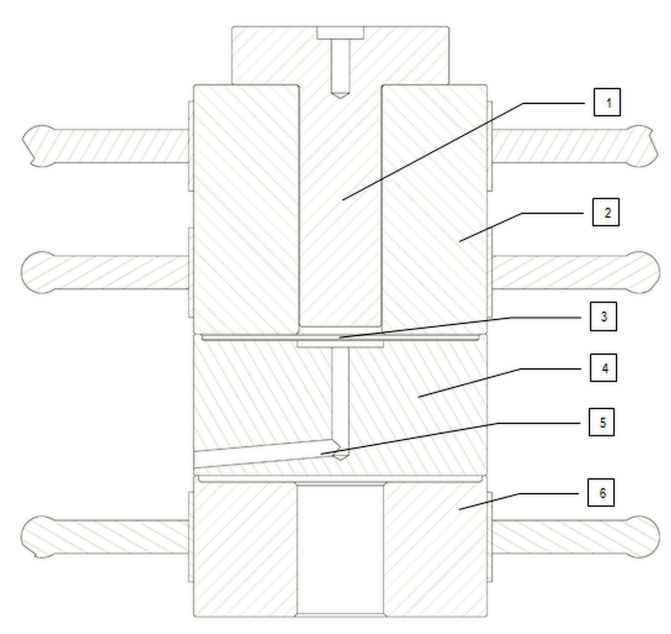

Figure 3. Schematic diagram of the pore solution expression apparatus: 1 - piston; 2, 4 - inner concentric cylinder; 3-sample; 5-drain tube; 6 - base. fitted on the bottom of the lower steel body just under the spiral recess connected with the drain tube which allowed draining of the fluid into the laboratory dish. The two cubic samples obtained after the flexural strength determination were used to expel the pore solution. No additional grinding or particle size reduction was done.

The $\mathrm{pH}$ value of the pore solution was measured immediately after it was expelled from the cement paste using a pH meter (Mettler Toledo, MPC 227). It was stored in sealed plastic test tubes to prevent reaction with atmospheric carbon dioxide for 24 hours, until the analysis of the trace elements content was done. The measured $\mathrm{pH}$ values are reported in Table 6 .

\section{Trace Elements Determination}

Levels of the selected trace elements ( $\mathrm{As}, \mathrm{Cd}, \mathrm{Co}, \mathrm{Cr}, \mathrm{Cu}, \mathrm{Hg}$, $\mathrm{Ni}, \mathrm{Pb}, \mathrm{Sb}, \mathrm{V}$ and $\mathrm{Zn}$ ) in unhydrated cement and pore solution were measured by ICP-MS on the same instrument used for soft water analysis. Unhydrated cement $(0.2000 \pm$ $0.0001 \mathrm{~g}$ ) was subjected to digestion (ETHOS UP Milestone device) using the mixture of nitric $(2.0 \pm 0.1 \mathrm{~mL})$, hydrochloric $(6.0 \pm 0.1 \mathrm{~mL})$, phosphoric $(1.0 \pm 0.1 \mathrm{~mL})$ and $(1.0 \pm$ $0.1 \mathrm{~mL}$ ) tetraflouroboric acid. The acid mixture contained

Table 6. $\mathrm{pH}$ values of pore solution after leaching.

\begin{tabular}{ccc}
\hline \multirow{2}{*}{$\begin{array}{c}\text { Hydration period } \\
\text { days }\end{array}$} & CEM I & CEM III \\
\cline { 2 - 3 } 2 & pH value & pH value \\
\hline 7 & 13.45 & 13.85 \\
28 & 13.44 & 13.77 \\
56 & 13.41 & 13.51 \\
90 & 13.37 & 13.34 \\
180 & 13.27 & 13.10 \\
365 & 12.95 & 12.66 \\
\hline
\end{tabular}

Table 7. Composition of calibration solutions for trace elements analysis by ICP-MS.

\begin{tabular}{|c|c|c|c|c|c|c|c|}
\hline \multirow[b]{2}{*}{ Element } & \multicolumn{7}{|c|}{ Concentration $^{(a)} / \mu \mathrm{g}^{-1}$} \\
\hline & $\begin{array}{c}\text { Standard } \\
\text { solution } 1\end{array}$ & $\begin{array}{c}\text { Standard } \\
\text { solution } 2\end{array}$ & $\begin{array}{c}\text { Standard } \\
\text { solution } 3\end{array}$ & $\begin{array}{c}\text { Standard } \\
\text { solution } 4\end{array}$ & $\begin{array}{c}\text { Standard } \\
\text { solution } 5\end{array}$ & $\begin{array}{c}\text { Standard } \\
\text { solution } 6\end{array}$ & $\begin{array}{l}\text { Standard } \\
\text { solution } 7\end{array}$ \\
\hline \multicolumn{8}{|c|}{ Calibration solution for soft water and pore solution analysis } \\
\hline As, $\mathrm{Cd}, \mathrm{Co}, \mathrm{Cr}, \mathrm{Cu}, \mathrm{Hg}, \mathrm{Ni}, \mathrm{Pb}, \mathrm{Sb}, \mathrm{V}, \mathrm{Zn}$ & 0.1 & 1.0 & 10 & 50 & 100 & - & - \\
\hline $\mathrm{Hg}$ & 0.02 & 0.5 & 1 & 1.5 & 2 & - & - \\
\hline $\mathrm{Ca}, \mathrm{Mg}$ & $0.01 \mathrm{mg} \mathrm{L}^{-1}$ & $0.1 \mathrm{mg} \mathrm{L}^{-1}$ & $1 \mathrm{mg} \mathrm{L}^{-1}$ & $5 \mathrm{mg} \mathrm{L}^{-1}$ & $10 \mathrm{mg} \mathrm{L}^{-1}$ & - & - \\
\hline \multicolumn{8}{|c|}{ Calibration solution for cement analysis } \\
\hline As, Cd, Co, Cr, Cu, Hg, Ni, Pb, Sb, V, Zn & 1 & 5 & 10 & 50 & 100 & 250 & 500 \\
\hline $\mathrm{Hg}$ & 0.01 & 0.02 & 0.5 & 1 & 1.5 & 2.0 & 5.0 \\
\hline
\end{tabular}

(a) Concentration of each specified element. 
aqua regia with the addition of tetraflouroboric acid to dissolve silicates, aluminium oxide and iron oxide. ${ }^{[75]}$ The digestion program included $20 \mathrm{~min}$ heating to $220^{\circ} \mathrm{C}$ and $15 \mathrm{~min}$ at $220^{\circ} \mathrm{C}$. The applied power of the digestion device was $1800 \mathrm{~W}$. The digestion temperature, time program and the acid mixture were adjusted to ensure complete decomposition of the samples and provide a clear solution. The whole digested volume from the pressure vessel was transferred to a volumetric flask and filled up with ultra pure water to $50.0 \mathrm{~mL}$. The pore solution was not subjected to digestion prior to the analysis. These samples were analyzed on the ICP-MS device with collision cell and by using the He mode to minimize the possible matrix and isobaric interferences. Additionally, the high matrix introduction plasma mode with $1: 8$ dilutions was used for cement analysis. The same acids used for the sample preparation or digestion were added to the blank and standard solutions to minimize the matrix effect. The calibration curves were created using a method blank without the trace elements and five or seven standard solutions (see Table 7). Equal portions of the internal standard solution were added to the blanks, standards and sample solutions. For each of the analyzed elements the appropriate internal standard was selected (see Table 8). The method blank (ultra pure water taken through the entire sample preparation), the calibration
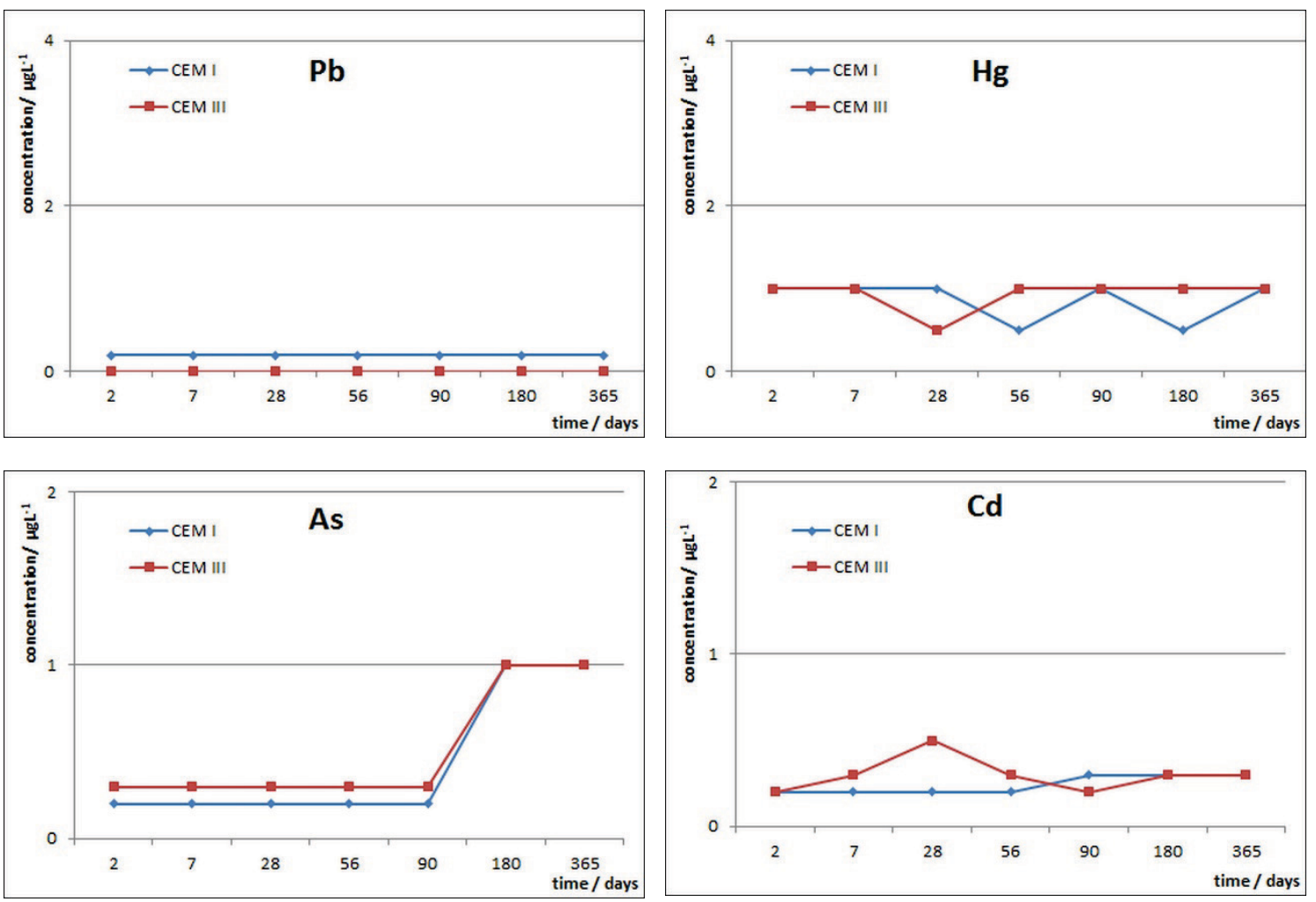

Figure 4. Development of the pore solution concentration of $\mathrm{As}, \mathrm{Cd}, \mathrm{Hg}$ and $\mathrm{Pb}$ in the course of time for leached cement pastes. verification standard (mid-range standard used for the calibration curve) and the laboratory control sample (midrange standard solution prepared from a different source) were used for the quality control during the analysis of each batch of samples. All samples, quality control samples,

Table 8. Trace elements and internal standards.

\begin{tabular}{cc}
\hline Element & Internal standard \\
\hline $\mathrm{As}$ & $\mathrm{Ge}^{72}$ \\
$\mathrm{Cd}$ & $\mathrm{In}^{115}$ \\
$\mathrm{Co}$ & $\mathrm{Sc}^{45}$ \\
$\mathrm{Cr}$ & $\mathrm{Sc}^{45}$ \\
$\mathrm{Cu}$ & $\mathrm{Sc}^{45}$ \\
$\mathrm{Hg}$ & $\mathrm{Bi}^{209}$ \\
$\mathrm{Ni}$ & $\mathrm{Sc}^{45}$ \\
$\mathrm{~Pb}$ & $\mathrm{Bi}^{209}$ \\
$\mathrm{Sb}$ & $\mathrm{In}^{115}$ \\
$\mathrm{~V}$ & $\mathrm{Sc}^{45}$ \\
$\mathrm{Zn}$ & $\mathrm{Ge}^{72}$ \\
$\mathrm{Ca}$ & $\mathrm{Sc}^{45}$ \\
$\mathrm{Mg}$ & $\mathrm{Sc}^{45}$ \\
\hline
\end{tabular}


Table 9. Operating parameters for Agilent 7800.

\begin{tabular}{|c|c|c|}
\hline Parameter & Value & \\
\hline Plasma mode & General purpose & $\mathrm{HMI}^{(\mathrm{a})}$ \\
\hline RF forward power / W & 1550 & 1600 \\
\hline Sampling depth / mm & 10 & 10 \\
\hline Carrier gas flow / L min ${ }^{-1}$ & 0.99 & 0.33 \\
\hline Spray chamber temperature $/{ }^{\circ} \mathrm{C}$ & 2 & 2 \\
\hline Extraction lens 1 / V & 0 & 0 \\
\hline Kinetic energy discriminator / V & 5 & 5 \\
\hline He cell gas flow ${ }^{(b)} / \mathrm{mL} \mathrm{min}^{-1}$ & 4.5 & 5 \\
\hline
\end{tabular}

blanks and standard solutions were measured in triplicate and the final result was reported as an average. The detection limit for each element was calculated from the average of ten-time repeated blank analyses plus the standard deviation. The clear sampler and skimmer cone were used for each batch analysis. The sensitivity data, the resolution / axis data and the lens parameters settings of the instrument were checked by tuning before the batch with a tune solution ( $1 \mathrm{ppb} \mathrm{Li}, \mathrm{Co}, \mathrm{Y}, \mathrm{Ce}, \mathrm{TI}$ ). Operating conditions of the instrument are shown in Table 9. Content
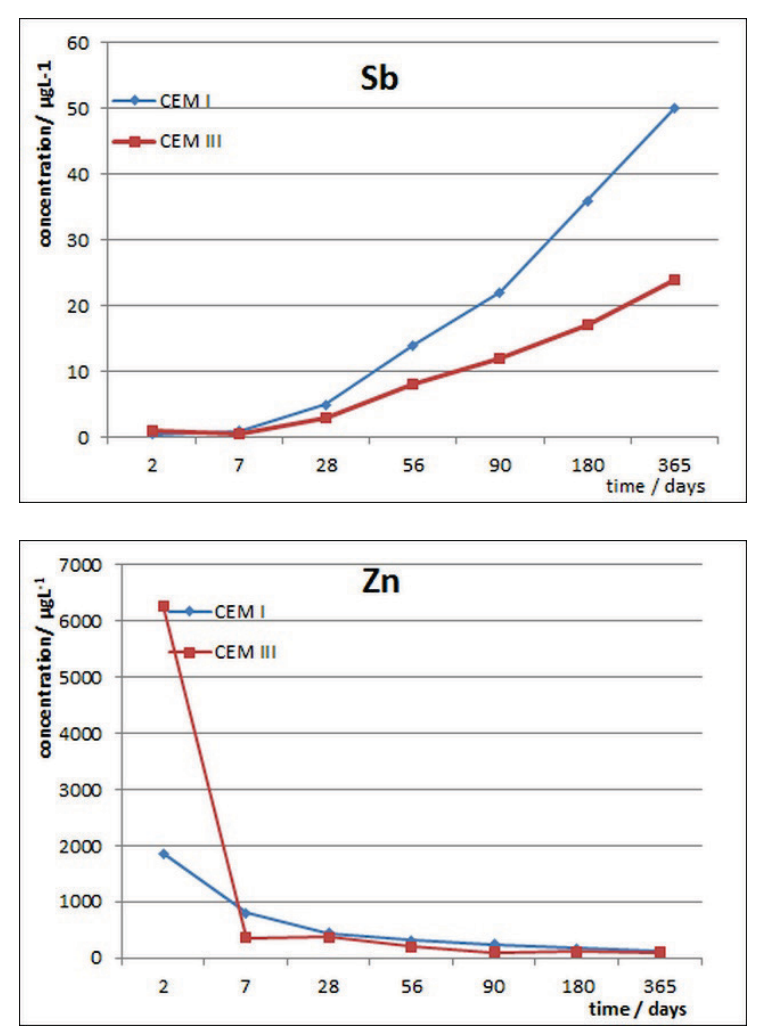

of the trace elements in CEM I and CEM III is reported in Table 10. The development of trace elements pore solution concentration in the course of time is shown in Figures 4, 5 and 6.

Table 10. Content of the trace elements in CEM I and CEM III.

\begin{tabular}{ccc}
\hline \multirow{2}{*}{ Trace element } & \multicolumn{2}{c}{ Cement } \\
\cline { 2 - 3 } Sb & CEM I & CEM III \\
\hline As & 10.3 & 36.4 \\
$\mathrm{Cd}$ & 4.30 & 4.40 \\
$\mathrm{Cr}$ & 0.50 & 0.60 \\
$\mathrm{Co}$ & 67.8 & 547 \\
$\mathrm{Cu}$ & 5.3 & 15.6 \\
$\mathrm{Hg}$ & 63.8 & 2368 \\
$\mathrm{Ni}$ & 0.03 & 0.02 \\
$\mathrm{~Pb}$ & 17.4 & 374 \\
$\mathrm{~V}$ & 1.19 & $<0.080^{(\mathrm{a})}$ \\
$\mathrm{Zn}$ & 39.5 & 205 \\
\hline (a) $\ln \mu \mathrm{kg} \mathrm{kg}^{-1}$ & 312 & 1056 \\
\hline
\end{tabular}
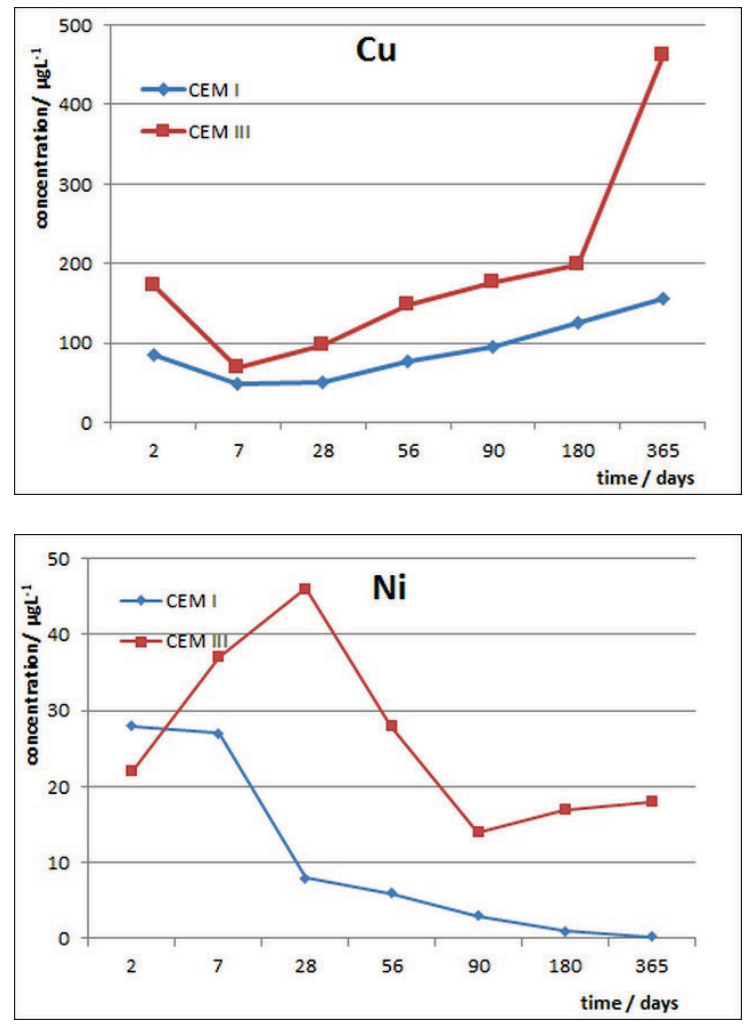

Figure 5. Development of the pore solution concentration of $\mathrm{Sb}, \mathrm{Cu}, \mathrm{Zn}$ and $\mathrm{Ni}$ in the course of time for leached cement pastes 

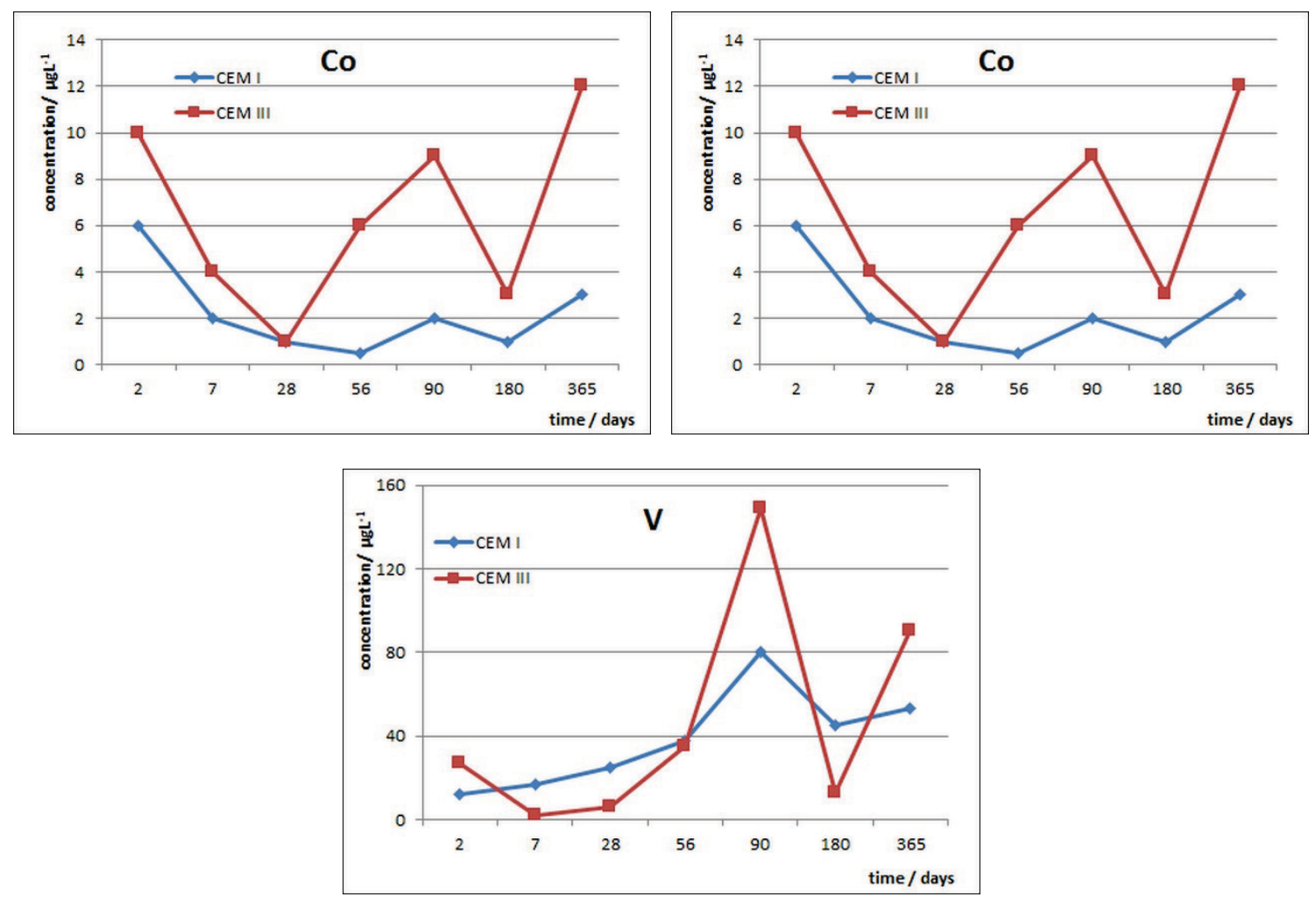

Figure 6. Development of the pore solution concentration of $\mathrm{Cr}, \mathrm{V}$ and $\mathrm{Co}$ in the course of time for leached cement pastes.

\section{RESULTS AND DISCUSSION}

Mass fraction of the major phases and elements in Tables 3 and 4 shows differences between CEM I and CEM III. The substantial glass content present in CEM III indicates that the principal source of these differences is the granulated blast furnace slag. It is a glassy material mainly consisting of silicon, aluminium and calcium oxides. ${ }^{[76]}$ Currently it is accepted for modern clinkers to contain glass only in rare cases. ${ }^{[77]}$ The glass phase content of $50-95 \%$ has been confirmed in the granulated blast furnace slag depending on the cooling method type. ${ }^{[78]}$

The final flexural and compressive strength reported in Table 5 shows a decrease within a one-year hydration period. In the 28 days hydration period no reduction in strength is observed. This indicates that hydration of both cement types in this period is not affected by leaching. The reduction of flexural strength of $46 \%$ is observed for the CEM I paste after 365 days. For the CEM III paste the reduction of flexural strength of $53 \%$ is observed after 180 days. Both, CEM I and CEM III pastes lose compressive strength after a 365 days hydration period for $13 \%$ and $61 \%$, respectively. The decline in flexural and compressive strength is the result of the long-term leaching process. Our finding is in full agreement with the works of other authors. ${ }^{[64,65]}$
Table 10 shows total concentration of the eleven trace elements in anhydrous CEM I and CEM III. The concentration of all elements, except mercury and lead, are higher in CEM III. These data correspond with findings of the other authors for the same cement types. ${ }^{[18]}$ The substitution of clinker by granulated blast furnace slag increases the trace elements concentration in CEM III, except for mercury and lead. The pure cement constituents, clinker, gypsum and slag, were not available for this research. Thus, a deep study of input pathways of the trace elements in cement within this research was not possible. Determined trace elements can be divided in two groups: elements with a concentration above $5 \mathrm{ppm}$ ( $\mathrm{Co}, \mathrm{Cr}, \mathrm{Cu}, \mathrm{Ni}$, $\mathrm{Sb}, \mathrm{Zn}$ and $\mathrm{V}$ ) and elements with a concentration below 5 $\mathrm{ppm}$ ( $\mathrm{As}, \mathrm{Cd}, \mathrm{Hg}$ and $\mathrm{Pb}$ ). Low concentration of some elements is connected with their volatility. Arsenic, cadmium, mercury and lead are considered as highly or moderate volatile elements in the cement kiln system. As it was mentioned in the literature review, they are hardly stabilized in Portland clinker. ${ }^{[18]}$ The other elements included in this research are considered as non-volatile, well incorporated within the clinker phases and thus highly abundant in cement. ${ }^{[6-18]}$ All selected trace elements in CEM I and CEM III pore solutions except chromium, vanadium and cobalt show a similar behaviour within a one-year hydration period. 
Concentration of the soluble trace elements in the pore solution, shown in Figures 3, 4 and 5, support their low solubility and immobilization in the highly alkaline cement paste. The extremely low pore solution concentration of arsenic, cadmium, mercury and lead corresponds to their low abundance in anhydrous cement. Cadmium and lead show a constant value in the course of time. Our finding for cadmium is similar to the work of Díez et al. reported for Portland cement pastes with a higher cadmium content exposed to degradation by carbonation. ${ }^{[4]}$ The mobility of cadmium is not correlated with its total content. Our finding for lead contradicts with the work of Vollpracht et al. who observed a slight increase of the lead pore solution concentration for pastes with a higher lead content exposed to leaching during a 28 days-hydration period. ${ }^{[54]}$ Mobility of lead is correlated to its total content. The alkalinity of pore solution reported in Table 6 strongly limits the mobility of cadmium and lead and they are not affected by leaching. Mercury behaves similarly to cadmium and lead but shows the highest solubility among the trace elements included in this research. This indicates that the higher content of mercury incorporated in the clinker phases could potentially present an environmental risk. A slight increase of the arsenic pore solution concentration indicates decrease in the calcium hydroxide content caused by leaching, therefore the higher content of arsenic in the cement paste could possible present an environmental risk.

The lower concentration of antimony at the beginning of hydration increases in the course of time in CEM I as well as in CEM III pore solutions. Our finding for antimony is in agreement with that in the work of Vollpracht et al. ${ }^{[54]}$ As it was described in the literature review, immobilization of antimony depends on the $\mathrm{pH}$ value and the calcium concentration. Table 6 shows a decrease of the $\mathrm{pH}$ value for CEM I and CEM III pore solutions. The increased solubility of antimony supports decalcification of hydrated cement phases caused by leaching. Antimony incorporated in the clinker phases could potentially present an environmental risk. Increase of the copper concentration in the pore solution is observed after 7 days. As it was mentioned in the literature review the only indicated mechanism of copper immobilization in the cement paste is the ion exchange with calcium from the C-S-H gel.[27] Our finding for copper indicates degradation of $\mathrm{C}-\mathrm{S}-\mathrm{H}$ and a potential environmental risk.

A quite high concentration of zinc decreases in the course of time. Our results correspond well with immobilization of zinc in different hydration phases proposed by other authors. ${ }^{[21-23]}$ Despite the decrease of $\mathrm{pH}$ values of the pore solutions, they are still alkaline. Mobility of zinc increases below $\mathrm{pH}$ 7. Behaviour of zinc in the pore solution does not indicate any deleterious reaction. Decreasing tendency is observed for nickel, too. Nickel is present in the form of hydroxide in the cement paste. ${ }^{[28]}$ Solubility of nickel hydroxide is $\mathrm{pH}$ dependent. In high alkaline media, at a $\mathrm{pH}$ above 11 , solubility of nickel increases. The decrease of nickel concentration in the pore solution corresponds to the decrease in $\mathrm{pH}$, Table 6 . Nickel behaviour in the pore solution indicates a deleterious reaction in the cement paste.

Chromium and vanadium show an increasing but a less clear trend. Cobalt pore solution concentration is scattered. A difference in behaviour of these elements in CEM I and CEM III pastes is observed. This indicates possible different incorporation of chromium, vanadium and cobalt within hydrated and non-hydrated CEM I and CEM III. It was not possible to correlate our results for these elements with degradation of the cement paste caused by leaching. The behaviour of these elements should be carefully considered in the environmental risk assessment due to ups and downs observed for these elements.

\section{CONCLUSION}

The leaching effect decreases the strength of the cement pastes after 180 days under the given experimental conditions. This indicates the need for long-term further tests.

Similar behaviour was observed for all selected trace elements in CEM I and CEM III pore solutions except for chromium, vanadium and cobalt. The possible different immobilization mechanism for these elements is indicated.

The observed trend of increasing concentrations in pore solutions of arsenic, mercury, antimony and copper and a decrease trend of nickel corresponds with the strength decrease for CEM I and CEM III and supports chemical degradation by leaching. Behaviour of chromium, vanadium and cobalt cannot be related to degradation by leaching due to observed ups and downs of their concentrations in pore solutions. Zinc, cadmium and lead are well immobilized in the hydrated cement pastes and are not affected by leaching. The observed increased concentration of arsenic, mercury, antimony and copper could possible present an environmental risk as well as the scattered behaviour of chromium, vanadium and cobalt. In the given experiment conditions nickel, zinc, cadmium and lead do not present an environmental risk.

The research work presented in this article shows that the trace elements have a potential to be used in durability investigations on cement pastes. Deep understanding of the trace elements immobilization in clinker and hydrated cement pastes as well as degradation reactions is necessary for this purpose. 


\section{REFERENCES}

[1] S. Bodaghpour, N.Biglari Joo, S. Ahamdi, Int. J. Geol., Earth. Environ. Sci. 2012, 6, 62-67.

[2] C. J. Engelsen, Effects of mineralizes in cement production, Trondheim, Concrete Innovation Centre, 2007, pp. 4-15.

[3] D. Herfort, G.K. Moir, V. Johansen, F. Sorrentino, H. Bollio-Arceo, Adv. Cem. Res. 2010 ,22, 187-194. https://doi.org/10.1680/adcr.2010.22.4.187

[4] J. M. Díez, J. Madrid; A. Macías, Cem. Concr. Res. 1997, 27(4), 479-485. https://doi.org/10.1016/S0008-8846(97)00041-0

[5] F. P. Glasser, in Lea's Chemistry of Cement and Concrete (Ed.: Peter C. Hewlett), Elsevier Ltd., Oxford, 1998., pp. 195-240. https://doi.org/10.1016/B978-075066256-7/50017-5

[6] S. Sinyoung, P. Songsiriritthigul, S. Asavapisit, P. Kajitvichyanukul, J. Hazard. Mater. 2011, 191, 296305. https://doi.org/10.1016/j.jhazmat.2011.04.077

[7] J. I. Bhatty, Effect of Minor Elements on Clinker and Cement Performance, Portland Cement Association, Shokie, 2006, pp. 35.

[8] H. Hornain, Rev. Mater. Constr. 1971, 671-672, 203-218.

[9] K. Kolovos, T. Tsivilis, G. Kakali, Cem. Concr. Compos. 2005, 27, 163-170.

https://doi.org/10.1016/j.cemconcomp.2004.02.003

[10] X. W. Ma, H. X. Chen, P. M. Wang, Cem. Concr. Res. 2010, 40, 1681-1687. https://doi.org/10.1016/j.cemconres.2010.08.009

[11] S. Sinyoung, E. Taweekitwanit, P. Kajitvitchyanukul, Adv. Mater. Res. 2015, 1103, 121-127.

https://doi.org/10.4028/www.scientific.net/AMR.1103.121

[12] H. Bolio-Arceo, F. P. Glasser, Adv. Cem. Res. 2000, 12, 173-179.

https://doi.org/10.1680/adcr.2000.12.4.173

[13] D. Knöfel, ZKG Int., 1978, 157-161.

[14] L. Wang, R. D. Li, Y. L. Li, L. H. Wei, Adv. Mat. Res. 2010, 347-353, 2160-2164.

https://doi.org/10.4028/www.scientific.net/AMR.347-353.2160

[15] Y. Yang, J. Xue, Q. Huang, Sci. World. J. 2013, 2013, 518676. https://doi.org/10.1155/2013/518676

[16] L. Wang, Y. Jin, R. D. Li, Y. Nie, Huagong Xuebao (Chin. Ed.) 2011, 62, 816-822.

[17] G. Cornelis, C. A. Johnson, T. V. Gerven, C. Vandercasteele, Appl. Geochem. 2008, 23, 955-976. https://doi.org/10.1016/j.apgeochem.2008.02.001

[18] M. Achternbosch, K. R. Bräutigam, N. Hartliebe; C. Kupsch, U. Richers, P. Stemmermann, M. Gleis., Heavy metals in cement and concrete resulting from co-inceretion of wastes in cement kilns with regard to the legitimacy of waste utilization, FZK, Karlsruhe, 2003, pp. 15-105.
[19] I. Odler in Lea's Chemistry of Cement and Concrete (Ed.: Peter C. Hewlett), Elsevier Ltd., Oxford, 1998., pp. 241-297.

https://doi.org/10.1016/B978-075066256-7/50018-7

[20] D. L. Cocke, M. Y. A. Mollah, J. Hazard. Mater. 1990, 24, 187.

[21] D. Bonen, S. L. Sarkar in Advances in Cement and Concrete Research, (Eds.: M. W. Grutzeck, S. L. Sarkar), American Society of Civil Engineers, New York, 1994, pp. 481-498.

[22] F. P. Glasser in Chemistry and Microstructure of Solidified Waste Forms, (Ed.: R. D. Spence), Lewis Publishers, Boca Raton, 1993., pp. 1-39.

[23] F. K. Cartledge, L. G. Butler, D. Chalasani, H. Eaton, F. P. Frey, E. Herrera, M. T. Tittlebaum, S. Yang, Envirnon. Sci. Technol. 1990, 24, 867-873. https://doi.org/10.1021/es00076a012

[24] D. C. Johnson, N. J. Coleman, J. Lane, C. D. Hills, A. B. Pole, in Waste Materials in Construction (Eds.: G. R. Woolley, J. J. J. Goumans, P. J. Wainwright), Elsevier, Amsterdam, 2000, pp. 1044-1049.

[25] C. H. Mattus, A. J. Mattus in Stabilization and Solidification of Hazardous, Radioactive and Mixed Wastes (Eds.: T. M. Gilliam, C. C. Wiles), ASTM, Philadelphia, 1996, pp. 609-633.

[26] A. Poletitini, R. Pomi, P. Sirini, Environ. Sci. Technol. 2002, 36, 1584-1591. https://doi.org/10.1021/es010002z

[27] O. P. Shrivastava, F. P. Glasser, J. Mater. Sci. 2002 36, 1584

[28] M. Atkins, F. P. Glasser, L. P. Moroni, J. J. Jack, Thermodynamic modeling of blended cements at elevated temperatures $\left(50-90^{\circ} \mathrm{C}\right)$, Aberdeen University, United Kingdom, 811 DoE1HMIP1RR/94.011, 1994.

[29] A. M. Scheidegger, E. Wieland, A. C. Scheinost, R. Dähn, P. Spieler, Environ. Sci. Technol. 2000, 34, 4545-4548. https://doi.org/10.1021/es0000798

[30] M. Vespa, D. Raehn, E. Wielnad, D. Grolimund, A. M. Scheidegger, Czech. J. Phys. 2006, 56D, D599-D607. https://doi.org/10.1007/s10582-006-0554-z

[31] K. Noshita, T. Nishi, T. Yoshida, H. Fujihara, N. Saito, S. Tanaka in Proceedings of the Material Research Society Symposium, Volume 663, Cambridge University Press, 2001, pp. 115-121. https://doi.org/10.1557/PROC-663-115

[32] I. Moulin, J. Rosea, W. Stone, J.-Y. Bottereo, F. Mosnier, C. Haelmel: in Waste Materials in Construction (Eds.: G. R. Woolley, J. J. J. Goumans, P. J. Wainwright), Elsevier, Amsterdam, 2000, pp. 269-280.

[33] F. Ziegler, R. Giere, C. A. Johnoson, Environ. Sci. Technol. 2001, 35, 4556-4561. https://doi.org/10.1021/es001768m 
[34] F. Ziegler, R. E. M. Scheidegger, C. A. Johnosn, R. Dahen, E. Wieland, Environ. Sci. Technol. 2001, 35, 1550-1555. https://doi.org/10.1021/es001437+

[35] P. Kumarathasan, G. J. McCarthy, D. J. Hassett, D. F. Pflughoeft-Hassett in Proceedings of the Material Research Society Symposium, Volume 178, Cambridge University Press, 1989, pp. 83-104.

[36] T. Phenrat, T. F.Marhaba, M. Rachakornkij, J. Hazard. Mat. 2005, 118, 185-195.

https://doi.org/10.1016/j.jhazmat.2004.10.019

[37] V. Dutré, C. Vandecasteele, Waste Manag. 1995, 15(1), 52-62. https://doi.org/10.1016/0956-053X(95)00002-H

[38] J. E. Aubert, B. Husson, N. Sarramone, J. Hazard. Mater. 2007, 147, 12-19.

https://doi.org/10.1016/j.jhazmat.2006.11.044

[39] G. Cornelis, B. Etschmann, T. V. Gerven, C. Vandecasteele, Cem. Concr. Res. 2012, 42, 1307-1316. https://doi.org/10.1016/j.cemconres.2012.06.004

[40] G. Cornelis, T. V. Gerven, R. Snellings, J. Elsen, C. Vandercasteele, Appl. Geochem. 2011, 26, 809-817. https://doi.org/10.1016/j.apgeochem.2011.02.002

[41] C. S. Poon, A. I. Clark, C. J. Peters, R. Perry, Waste Manage. Res., 1985, 3, 127-142. https://doi.org/10.1177/0734242X8500300114

[42] K. Andersson, B. Allard, M. Bengtsson, B. Magnusson, Cem. Concr. Res. 1989, 19, 327-332. https://doi.org/10.1016/0008-8846(89)90022-7

[43] M. A. Bérubé, C. Tremblay, B. Fournier, M. D. Thomas, D. B. Stokes, Cem. Concr. Res. 2004, 34, 1645-1660. https://doi.org/10.1016/j.cemconres.2004.03.025

[44] S. Brendle, M. R. de Rooij, K. van Breugel, Restor. Build. Monum. 2008, 14, 141-152. https://doi.org/10.1515/rbm-2008-6207

[45] S. Diamond., Cem. Concr. Res. 1981, 11, 383-394. https://doi.org/10.1016/0008-8846(81)90110-1

[46] P. Longuet, L. Burglen, A. Zelwer, Rev. Mater. Constr. 1973, 676, 35-41.

[47] P. Lorenzo, S. Goñi, S. Hernandez, A. Guerrero, J. Am. Ceram. Soc. 1996, 79, 470-474. https://doi.org/10.1111/j.1151-2916.1996.tb08146.x

[48] B. Lothenbach, F. Winnefeld, Cem. Concr. Res. 2006, 36, 209-226.

https://doi.org/10.1016/j.cemconres.2005.03.001

[49] B. Lothenbach, F. Winnefeld, C. Alder, E. Wieland, P. Lunk, Cem. Concr. Res. 2007, 37, 483-491. https://doi.org/10.1016/j.cemconres.2006.11.016

[50] C. L. Page, O. Vennesland, Mater. Struct. 1983, 1, 19-25. https://doi.org/10.1007/BF02474863

[51] A. Vollpracht, Einbindung von Schwermetallen in Portlandzementstein. Schriftenreihe Aachener Beiträge zur Bauforschung, PhD Thesis, RWTH Aachen University, 2012.
[52] A. Vollpracht; B. Lothenbach, R. Snellings, J. Haufe, Mater. Struct. 2016, 49, 3341-3367. https://doi.org/10.1617/s11527-015-0724-1

[53] J. Kempel, O. Çorpuroğlu, in Proceedings of the15 $5^{\text {th }}$ Euroseminar on Microscopy Applied to Building materials, Delft University of Technology, Deft, 2015, pp. 287-296.

[54] A. Vollpracht; W. Brameshuber, Cem. Con. Res. 2016, 79, 76-92.

https://doi.org/10.1016/j.cemconres.2015.08.002

[55] F. Adenot, M. Buil, Cem. Conc. Res. 1992, 22, 489-496. https://doi.org/10.1016/0008-8846(92)90092-A

[56] M. Mainguy, C. Tognazzi, J. M. Torrenti, F. Adenot, Cem. Concr. Res. 2000, 30, 83-90. https://doi.org/10.1016/S0008-8846(99)00208-2

[57] T. H. Wee, J. Zhu, H.T Chua, S. F. Wong, ACl. Mater. J. 2001, 98, 184-193.

[58] S. Kamali, B. Gerrard, M. Moranville, Cem. Concr. Compos. 2003, 25, 451-458. https://doi.org/10.1016/S0958-9465(02)00085-9

[59] J. Jain, N. Neithalath, Cem. Concr. Comps. 2009, 31, 176-185. https://doi.org/10.1016/j.cemconcomp.2009.01.003

[60] F. P. Glasser, J. Marchand, E. Samson, Cem. Concr. Res. 2008, 38, 226-246. https://doi.org/10.1016/j.cemconres.2007.09.015

[61] P. Faucon, F. Adenot, M. Jorda, R. Cabrillac, Mater. Struct. 1997, 30, 480-485. https://doi.org/10.1007/BF02524776

[62] P. Faucon, F. Adenot, J. F. Jacquinot, J. C. Petit, R. Cabrillac, M. Jorda, Cem. Concr. Res. 1998, 28, 847-857. https://doi.org/10.1016/S0008-8846(98)00053-2

[63] R. D. Hooton, M. D. A. Thomas, T. Ramlochan, Adv. Cem. Res. 2010, 22, 203-210. https://doi.org/10.1680/adcr.2010.22.4.203

[64] C. Carde, R. Franqois, J. M. Torrenti, Cem. Concr. Res. 1996, 26, 1257-1268. https://doi.org/10.1016/0008-8846(96)00095-6

[65] F. H. Heukamp, F. J. Ulm, J. T. Germaine, Cem. Concr. Res. 2001, 31, 767-774. https://doi.org/10.1016/S0008-8846(01)00472-0

[66] G. J. Verbeck, R. H. Helmuth in Proceedings of the 5th International Symposium on the Chemistry of Cement, Volume 1, Tokyo, 1968, pp. 1-32.

[67] P. K. Mehta, P. J. M. Monteiro, Concrete: Microstructure, Properties and Materials, McGraw-Hill, New York, 2006, pp. 121-199.

[68] Q. Y. Chen, M. Tyrer, C. D. Hills, X. M. Yang, P. Carey, Waste Manag. 2009, 29, 390-403. https://doi.org/10.1016/j.wasman.2008.01.019

[69] Croatian Standard Institute, HRN EN 197-1:2012 Cement - Part 1: Composition, specifications and conformity criteria for common cements (EN 197-1:2011). 
[70] Croatian Standard Institute, HRI CEN/TR 196-4:2017 Methods of testing cement - Part 4: Quantitative determination of constituents (CEN/TR 196-4:2007).

[71] T. Degen, M. Sadki, E. Bron, U. König, G. Nénert, Powder Diffr. 2014, 29(S2), S13-S18. https://doi.org/10.1017/S0885715614000840

[72] Croatian Standard Institute, HRN EN 196-2: 2013 Methods of testing cement - Part 2. Chemical analysis of cement (EN 196-2:2013).

[73] Croatian Standard Institute, HRN EN 17294-2:2016 Water quality - Application of inductively coupled plasma mass spectrometry (ICP-MS) - Part 2: Determination of selected elements including uranium isotopes (ISO 17294-2:2016; EN ISO 17294-2:2016).
[74] Croatian Standard Institute, HRN EN 196-1: 2016 Methods of testing cement - Part 1: Determination of strength (EN 196-1:2016).

[75] A. Santro, A. Held, T. P. J. Linsinger, A. Perez, M. Ricci, Trends Anal. Chem. 2017, 89, 34-40. https://doi.org/10.1016/j.trac.2017.01.010

[76] X. Y. Wang, H. S. Lee, K. B. Park, J. J. Kim, J.S. Golden, Cement Concrete Comp. 2010, 32, 468-477. https://doi.org/10.1016/j.cemconcomp.2010.03.006

[77] H. F. W Taylor, Cement Chemisty, Thomas Telford Services Ltd, London, 2004, pp. 78.

[78] H. F. W Taylor, Cement Chemisty, Thomas Telford Services Ltd, London, 2004, pp. 262. 